\section{Boost for industrially relevant research in India}

New Delhi

THE report of a review committee that recommended revamping of the Council of Scientific and Industrial Research (CSIR) was finally accepted early this month with modifications suggested by the scientific advisory committee to prime minister Rajiv Gandhi. The report was hanging fire for more than a year because of CSIR's objections to the suggested closure of all its 100 extension centres and transfer of four of its laboratories to concerned government departments.

It has now been decided that the laboratories will stay with CSIR and closure of extension centres will be effected on a selective basis. According to CSIR director-general, Dr A.P. Mitra, other recommendations of the committee have been accepted and will be implemented in three months to give CSIR a new look.

Under the new scheme, the CSIR headquarters in Delhi gives up administrative and financial control over its 41 laboratories in favour of greater autonomy. It will confine its role to policy formulation, manpower and technology development. The laboratories will earn one-third of their keep through consultancy and other services to industry and government, the rest coming from the taxpayers.

The proposed structural changes aim at strengthening CSIR's link with industries and user agencies in the government. Henceforth the laboratories will work on research and development projects whose priorities will be identified by a high-level mission-oriented projects. the director's performance. bear. advisory board headed by an eminent technologist from outside. Besides scientists from CSIR, the board will have members representing industries and user agencies and will be responsible for resource allocations and review of work in progress. Experts from outside CSIR will also be included in half a dozen technical advisory boards which will undertake technology forecasting and formulate

CSIR has also agreed to the committee's recommendation for a fixed six-year term for laboratory direction. Extension will be given in exceptional cases after a review of

An exception made in the case of $\mathrm{Dr}$ Pushpa Bhargava, director of the Centre for Cellular and Molecular Biology (CCMB) in Hyderabad, has kindled a controversy. Bhargava, who had exceeded the six-year term and was to attain retirement age on February 28, was first given six weeks' notice to leave, but the order was retracted three weeks later and he was given a two-year extension.

According to CSIR the decision to extend his tenure was taken at the highest level, meaning the prime minister, who reportedly received letters from a section of CCMB scientists and some Nobel laureates, including Francis Crick, urging him to let Bhargava continue. Whether the six other directors who have completed the six-year term will get a similar extension depends on the influence they can bring to

K.S. Jayaraman

\section{Soviet demographers come clean}

\section{London}

Soviet planners "fail to see the human being for the worker", according to Professor Dmitri Valentei of the University of Moscow Centre for the Study of Population Problems.

Writing in the daily Sotsialisticheskaya Industrriya, Valentei complains that responsibility for vital regional developments has too often been left to "dilettantes" who have failed to provide redeployed groups of workers with the necessary social infrastructure, with the result that there has been a drift of population from less favoured areas to the large cities, while smaller towns have declined.

Valentei says that, while the State Commission for Labour of the USSR has now been made responsible for "an effective demographic policy", it simply does not have enough expertise to do the job. Valentei offers his university's services for training people.

The Soviet Union has two urgent demo- graphic problems - an ageing population and and growing ethnic imbalance. While the Soviet population has increased by a third since 1959 , the number of pensioners has increased by 78 per cent.

Life expectancy, which fell in the 1970s, is now increasing again (but Valentei says that is is still "about $\mathbf{1 0}$ years for men and 8 years for women less than the best world indices"). There has also been a slight increase of the birth rate.

Valentei also notes the relatively rapid growth of the traditional islamic islands of Central Asia, Kazakhstan and Azerbaijan, where 18 per cent of the Soviet population appears responsible for $\mathbf{4 0}$ per cent of population growth. One dilemma brought to light by glasnost is that infant mortality is relatively higher in the moslem republics (in excess of 30 deaths per 1,000 births), as is the incidence of congenital defects. Steps taken to change this state of affairs could worsen the ethnic imbalance in the short run.

\section{Embryo research criminal}

\section{Munich}

IGNORING protests from scientific and medical organisations, the West German cabinet on 10 February recommended criminal penalties for research on human embryos and manipulation of human germ-line cells. Health Minister Rita Süssmuth (Christian Democrat) also recommended that artificial insemination be made illegal for women with infertile husbands and for unmarried couples.

The cabinet broadly followed the counsel of the Benda commission, created by the Justice and Research and Technology Ministries in 1984. But by making embryo research a criminal act, it came into conflict with the Max Planck Society, the Bundesärztekammer (a physicians' professional association) and other scientific organizations.

The cabinet issued a third recommendation forbidding surrogate motherhood the bearing of a child for a childless couple by a so-called "mother-for-hire". The ban would extend even to the advertising of surrogate mother services. This measure was meant to close a loophole that had allowed the affiliate of a US surrogacy firm to operate until recently in Frankfurt (see Nature 329, 577; 1987).

Research organisations agreed in principle to several of the recommendations, for example, to the ban on the creation (cloning) of human beings from totipotent cells or the ban on creating human-animal chimaeras? But Max Planck Society spokesman Peter Gutjahr-Löser protested the "portrayal of research as bordering on criminal activity", saying that such laws "might discourage young researchers" from entering fields such as molecular biology.

The president of the Bundesärztekammer, Karsten Vilmar, has also complained, in a radio interview, that embryo research is imperative and that scientific freedom is endangered by laws that are too restrictive.

Infertility is a growing problem in West Germany, but Health Minister Süssmuth wants to ensure that in vitro fertilization (IVF) does not become a "tool for family planning". Couples who want but cannot have children comprise 10 to 15 per cent of all married couples in West Germany. Süssmuth suggests more intensive counselling as well as research into the causes of infertility, with IVF to be used only as a last resort.

The Ministry for Youth, Families, Women and Health will present a proposal for a law on surrogate motherhood later this year. The Justice Ministry is responsible for proposing a law covering embryo research. 